\title{
Immature Gastric Teratoma
}

National Cancer Institute

\section{Source}

National Cancer Institute. Immature Gastric Teratoma. NCI Thesaurus. Code C5256.

An immature teratoma that arises from the stomach. 